\title{
"Champimer" project: investigation of fungal diversity at the air-water interface of maritime environment
}

\author{
Richard Pougnet ${ }^{1,2,3}$, Laurence Pougnet ${ }^{1,4,5}$, Solène Le Gal ${ }^{5,6}$, \\ Brice Loddé ${ }^{1,2,7}$, Gilles Nevez ${ }^{5,6}$ \\ ${ }^{1}$ French Society of Maritime Medicine (Société Française de Médecine Maritime [SFMM]), Brest, France \\ ${ }^{2}$ Environmental Diseases Unit, University Hospital, CHRU, Brest, France \\ ${ }^{3}$ Universitive Preventive Medicine Unit (Service Universitaire de Médecine Préventive et de Promotion \\ de la Santé [SUMPPS]), Université de Bretagne Occidentale, Brest, France \\ ${ }^{4}$ Military Hospital, Clermont-Tonnerre, Brest, France \\ ${ }^{5}$ Groupe d'Etudes des Interactions Hôte-Pathogène (GEIHP), Université de Bretagne Occidentale, Brest, France \\ ${ }^{6}$ Laboratoire de parasitologie et mycologie médicales (UF 8872), CHRU, Brest, France \\ ${ }^{7}$ Optimisation des Régulations Physiologiques (ORPHY), Université de Bretagne Occidentale, Brest, France
}

The marine environment is known for its biological and microbiological diversity. A recent review of the literature has described the diversity of pathogen microorganisms in seawater [1]. Moreover, it is well-known that the air contains several pathogenic microorganisms. But few studies investigate it. Marks et al. [2] found between 0 and 1200 CFU fungus per cubic meter of air within the maritime environment, depending on the location and the seasons; however, no fungus identification was given. The aim of the "Champimer" project is to investigate the fungus diversity at the air-water interface of maritime environment. This project is part of a partnership between the French Society of Maritime Medicine, the Resource Centre for Occupational and Environmental Pathologies of the University Hospital of Brest, the Medical Analysis Laboratory of the Military Hospital of Brest, and the Host-Pathogen Interaction Study Group of the University of Brittany-Loire.

Our study comprises four air sampling campaigns, one of each season, on Brest Harbour, Brest roadstead and on the Iroise Sea, in order to draw up a mycological cartography applied to military sailors, fishermen, as well as leisure sailors (Fig. 1). The air samples were taken from the open air, on the wheelhouse's roof of a ship belonging to the university. This ship is a trawler adapted for scientific research. Air was impacted in $15 \mathrm{~mL}$ of liquid medium using the Coriolis $\mu^{\circledR}$ air sampler (10 min, $300 \mathrm{~L} / \mathrm{min}$ ). After centrifugation, the pellet was divided for fungus isolation on agar media malt agar (incubated at $27^{\circ} \mathrm{C}$ ), DG18 (incubated at $27^{\circ} \mathrm{C}$ ) and DG18 (incubated at $37^{\circ} \mathrm{C}$ ). The identification of fungi was based on macroscopic and microscopic examination, and by analysing $28 \mathrm{~S}$ and ITS loci when fungi were not microscopically identified.

We have already realised and analysed air samples collected during the winter. No cultivable fungi were detected in samples taken in the Iroise Sea, whereas samples taken on Brest Harbour and Brest roadstead showed Cladosporium sp., Eutypa lata or Aspergillus section fumigati.

Aspergillus and Cladosporium may induce asthma manifestations or keratitis [3-5]. Cladosporium cladosporioides was also described to cause dermatological disease [6]. We aim to explore the fungal diversity over the four seasons on Brest Harbour, Brest roadstead and on the Iroise Sea and to collect epidemiological and clinical data on sea users.

These first results showed some fungi at the air-seawater interface in winter. The origin of these fungi may be telluric. This project will be proceeded over a year, three seasons more. 


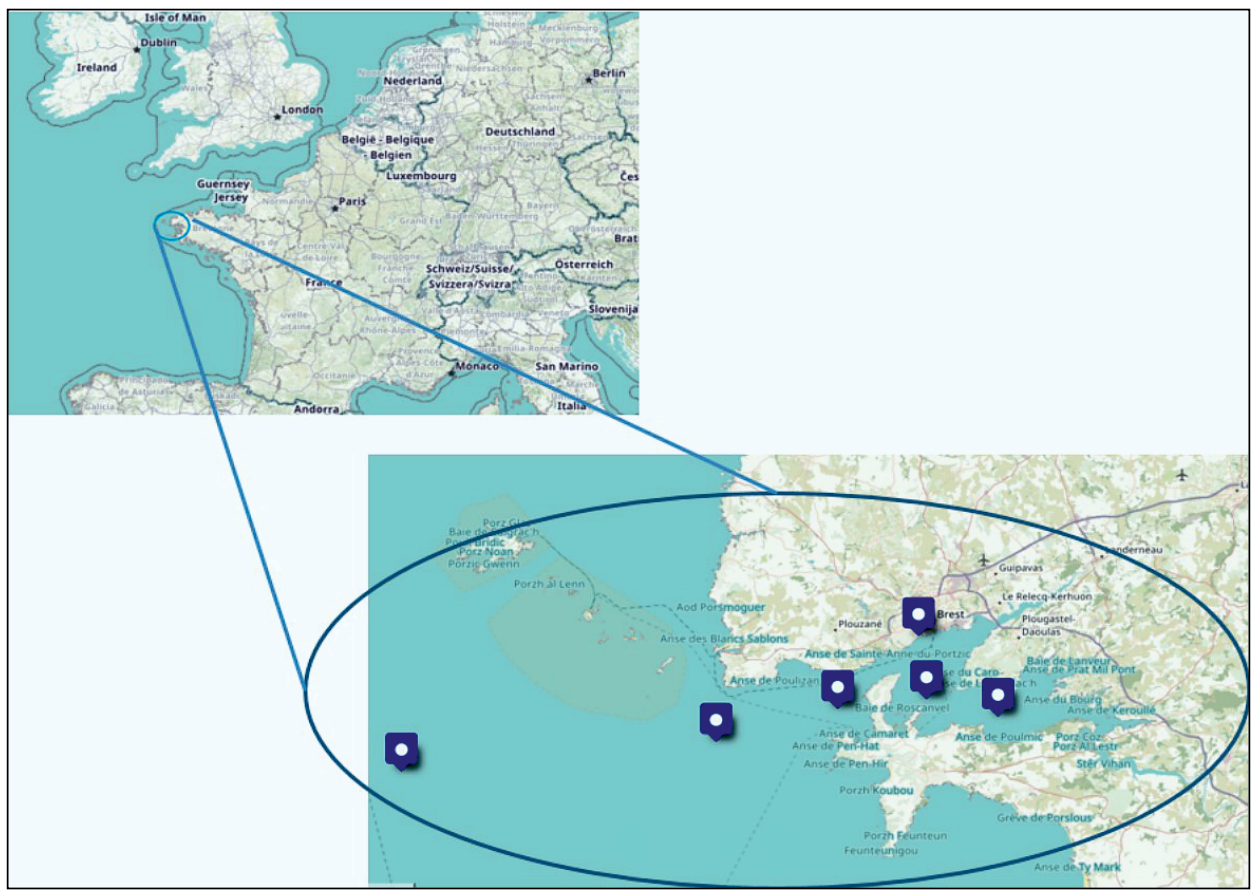

Figure 1. Spots of the air-water interface samples

\section{REFERENCES}

1. Pougnet R, Pougnet L, Allio I, et al. Maritime environment health risks related to pathogenic microorganisms in seawater. Int Marit Health. 2018; 69(1): 35-45, doi: 10.5603/IMH.2018.0006, indexed in Pubmed: 29611612.

2. Marks $\mathrm{R}$, Kruczalak $\mathrm{K}$, Jankowska $\mathrm{K}$, et al. Bacteria and fungi over the Gulf of Gdansk and Baltic sea. Aerosol Science. 2001; 32: 237-250.

3. Cheng $\mathrm{SCH}$, Lin YY, Kuo CN, et al. Cladosporium keratitis: a case report and literature review. BMC Ophthalmol. 2015; 15: 106, doi: 10.1186/s12886-015-0092-1, indexed in Pubmed: 26286482
4. Bousquet J, Michel FB. Specific Immunotherapy in Asthma. Allergy and Asthma Proceedings. 1994; 15(6): 329-333, doi: 10.2500/1 08854194778816562.

5. Sharpe RA, Bearman N, Thornton CR, et al. Indoor fungal diversity and asthma: a meta-analysis and systematic review of risk factors. J Allergy Clin Immunol. 2015; 135(1): 110-122, doi: 10.1016/j. jaci.2014.07.002, indexed in Pubmed: 25159468.

6. Nath R, Barua S, Barman J, et al. Subcutaneous mycosis due to Cladosporium cladosporioides and Bipolaris cynodontis from Assam, north-east India and review of published literature. Mycopathologia. 2015; 180(5-6): 379-387, doi: 10.1007/s11046-015-9926-x, indexed in Pubmed: 26198088. 